Federal Reserve Bank of Minneapolis

Research Department

\title{
On Efficiently Financing Retirement
}

\author{
Ellen R. McGrattan and Edward C. Prescott
}

November 2011

Working Paper 692

\begin{abstract}
A problem facing the United States and many other countries is how to finance retirement consumption as the number of their workers per retiree falls. The problem with a savings for retirement systems is that there is a shortage of good savings opportunities given the nature of most current tax systems and governments' limited ability to honor the debt it issues. We find that eliminating capital income taxes will greatly increase saving opportunities and make a savings-for-retirement system feasible with only modest amount of government debt. The switch from a system close to the current U.S. retirement system, which relies heavily on taxing workers' incomes and making lump-sum transfers to retirees, to one without income taxes will increase the welfare of all birth-year cohorts alive today and particularly the welfare of the yet unborn cohorts. The equilibrium paths for the current and alternative policies are computed.

JEL Nos: E20, G00, G18, H21, H61

Keywords: Government debt; Tax systems; Efficient taxation; Quantitative OLG

*McGrattan, Federal Reserve Bank of Minneapolis and University of Minnesota; Prescott, Arizona State University and Federal Reserve Bank of Minneapolis. We thank many seminar participants for useful comments and in particular we thank Kevin Donovan for his suggestions. We also thank Ed Schee and Chris Herrington. A highly preliminary version of this paper was presented at Minneapolis Federal Reserve Bank Conference honoring Gary Stern. The views expressed herein are those of the authors and not necessarily those of the Federal Reserve Bank of Minneapolis or the Federal Reserve System.
\end{abstract}




\section{Introduction}

An important policy issue is how to finance retirement consumption in light of the falling number of workers per retiree in many countries including the United States. This fall is due to population growth rates slowing and mortality rates falling. ${ }^{1}$ In the tradition of Ramsey we rule out lump-sum taxes to finance retirement consumption. We also limit the amount of debt that a government can honor, because at some level of debt, potential lenders will not lend to the government because of default fears. Given these constraints, most retirement consumption must be financed by a combination of retirees selling assets they accumulated over their working-life and by lump-sum transfers to retirees.

The problem with the use of the lump-sum transfers to retirees system is that there is a dead-weight loss associated with taxing workers to finance these transfers. A problem with relying on savings to finance all retirement consumption, at least with the current U.S. tax system, is that the value of equity is too small. In a closed economy, private savings is equal to equity plus government debt as net lending between households and the businesses they own is zero. Saving abroad is not a solution because net foreign savings summed over all countries is zero.

We find large social gains to the elimination of capital income taxation, because private savings opportunities are dramatically increased. The increase occurs for two reasons. First, there is the well-known reason that with this tax policy the capital-output ratio is higher. Second, there is a not so well-known and quantitatively important reason: The no-capital-income-tax policy results in a large increase in the value of private business equity. ${ }^{2}$ The increase in the market value of equity permits the financing of retirement consumption through savings and there is no

\footnotetext{
${ }^{1}$ See De Nardi, Imrohorglu, and Sargent (1999) for an analysis.

${ }^{2}$ For a closed economy, the net worth of the private sector is the value of equity plus the net government debt.
} 
need to tax workers’ labor income to finance lump-sum transfers to retirees. This is with demographics that result in the number of workers per retiree falling from its current value of three to only two.

We revise the national accounts so that they better conform to the theory used here, and throughout this paper we use these adjusted accounts. One major revision is that we use producers prices consistently, which means subtracting consumption taxes from income and private consumption. A second adjustment is that we add the implicit services of consumer durables to consumption. This adjustment increases gross national product (GNP). Consumer durable expenditures are treated as investments.

An important point is that the stock of (non-human) capital is larger than the commonly used value in macroeconomic analyses. For example, Auerbach and Kotlikoff (1987) use a capital share consistent with a capital stock of 2.8 times GNP. ${ }^{3}$ With a capital stock of 3.5 times GNP, Birkeland and Prescott (2007) show that a large government debt to GNP ratio is needed with a savings-for-retirement system and current demographic trends.

Our estimate is that the U.S. capital stock at reproduction cost is about 5.8 GNPs and that changing the tax system appropriately will increase this stock to 7.1 GNPs. Thus, there is not the need for large government debt with a saving-for-retirement system even if the number of workers per retiree falls from three to two. ${ }^{4}$

We make five additions to fixed capital assets to obtain the larger capital stock. First, we include the value of land, which is in fact mostly capital as nearly all its value is the result of past

\footnotetext{
${ }^{3}$ We do not include non-rival human capital in the model's capital stock. The reason we do not include this large stock of capital is that in retirement human capital cannot be sold and the proceeds used to finance retirement consumption.

${ }^{4}$ The problem is not that the aging population will lead to over-capital accumulation with a savings-for-retirement system. Absent forced savings, there cannot be an equilibrium with over capital accumulation if debt contracts are permitted. This was established by Thompson (1967, p. 1206). Abel, Mankiw, Summers and Zeckhauser's (1989) findings that over capital accumulation was not the case U.S. in the period they examined hold for the economies and policies we consider.
} 
investments made in improving undeveloped land. ${ }^{5}$ Second, we include the stock of inventories. Third, we include the stock of consumer durables. Fourth, we add government owned capital as its services are inputs to production. These additions increase the stock of tangible capital from 3.0 GNPs to 4.1 GNPs. Finally, we include the McGrattan and Prescott (2010) estimate of intangible business capital, 1.7 GNPs, to obtain a current capital stock measure of 5.8 GNPs. We use an overlapping-generations structure; therefore, government debt is part of the private sector's net worth. We compute not only the balanced growth paths, but also the equilibrium transition paths, with the initial state calibrated to the current U.S. economy, for two alternative tax systems and two alternative demographic assumptions. The first tax system is essentially the one currently in use with its high income tax rates and large transfers to retirees. The second one has no income taxes and makes no retirement-transfers to retirees. The first choice of demographics is one with three workers per retirees now and in the future. The second choice is one which results in the number of workers per retiree falling to two.

The balanced growth paths are determined for both demographics and welfare comparisons made. The measure of welfare is remaining-lifetime consumption equivalents for those birth-year cohorts currently alive and lifetime consumption equivalents for those joining the workforce in the future.

Recent research has focused on the role of social security with incomplete markets. Krueger and Kubler (2002), for example, show that a pay-as-you-go social security system may be Pareto improving due to improved risk sharing between generations. Conesa and Krueger (1999) find that idiosyncratic income uncertainty within generations implies a majority of current

\footnotetext{
${ }^{5}$ See Rossi-Hansberg and Wright (2007) for introducing developers into a competitive equilibrium model with endogenous cities. Apparently, the BEA does not included land as a component of fixed assets at reproduction costs because they do not have good measures of these costs. The lack of measures of the value of land at reproduction costs is why we use market values in our capital stock number.
} 
voters lose in the transition from a fully funded system to a pay-as-you-go system. We provide a reform in which no cohort incurs welfare losses in the transition. Conesa, Kitao, and Krueger (2009) find that in an OLG model with borrowing constraints, idiosyncratic income risk, and no annuity markets, the optimal capital tax rate may be positive. This is based on maximization of a social welfare function. We compute lifetime welfare gains for every birth-year cohort, and do no restrict attention to steady states or a particular social welfare function.

In Section 2 we present the model used to evaluate the alternative retirement financing systems. In Section 3 we develop the income and product accounts, the capital accounts, and the balance sheets. To do this we use the U.S. Department of Commerce's National Income and Product Accounts (NIPA) appropriately modified to be consistent with theory and the U.S. Department of Commerce Fixed Capital Accounts. In Section 4, we select the parameters to be consistent with these accounts and with demographic data. We verify that the model's prediction for household net worth is close to the Federal Reserve's Flow of Funds reported value. In Section 5, we report the balanced growth paths for an economy where the growth rate of new work-force entrants continues at 1 percent annually and for an economy where there is no growth in the number of new work-force entrants for both the current tax system and the proposed alternative. We also report the equilibrium paths if there is no growth in the number of workforce entrants and the welfare differences for each birth-year cohort. In Section 6, we provide a summary of the findings and some concluding remarks.

\section{The Model Economy Used}

The model economy has an overlapping-generation structure with measure $n_{t}^{1}$ arriving workingage households at the beginning of date $t$. Years since entry into the workforce is called age and is denoted by $j$. The number of age $j$ households at date $t$ is $n_{t}^{j}$. The maximum possible age is 
$J$. The probability of an age $j<J$ household at date $t$ surviving to age $j+1$ is $\sigma_{t}^{j}>0$. The $n_{t}^{1}$ are parameters that define the population dynamics. We restrict attention to

$$
n_{t+1}^{1}=(1+\eta) n_{t}^{1}
$$

with $n_{0}^{1}=1$, where $\eta$ is the growth rate of households entering the workforce.

\section{State vector}

To simplify notation, we use the recursive competitive equilibrium language. Given that the economy is non-stationary, $t$ is included as an element of the aggregate state vector. All stocks are beginning of period stocks. The variables that define the aggregate state vector $s$ are as follows:

(i) $\quad t=0,1,2, \ldots$ is the time period.

(ii) $\left\{a^{j}, n^{j}\right\}$ are the assets $a^{j}$ (net worth) of an age $j$ household and $n^{j}$ the measure of age $j$ households.

(iii) $\quad B$ is the government debt owned by the private sector.

(iv) $K_{T 1}$ and $K_{T 2}$ are the aggregate tangible capital stocks for the two business sectors (described below).

(v) $\quad K_{I 1}$ and $K_{I 2}$ are the aggregate intangible capital stocks for two business sectors. The reason that two business sectors are needed is that different legal categories of businesses are subject to very different tax systems and, as a consequence, the market values of their equity and net debt relative to their capital stock are different. The empirical counterpart of sector 1 is Schedule C corporations that are subject to the corporate income tax. Schedule S and other corporations that distribute all profits to owners, unincorporated businesses, and household 
businesses are in sector 2. Government enterprises and the government production sector are in sector 2 as well.

\section{Prices and policy}

The equilibrium price sequences are interest rates $\left\{i_{t}\right\}$ and wage rates $\left\{w_{t}\right\}$.

Policy specifies the following sequences:

(i) Tax rates $\tau=\left\{\tau_{t}^{c}, \tau_{1 t}^{d}, \tau_{2 t}^{d}, \tau_{t}^{\ell}, \tau_{1 t}^{\pi}\right\}$, where $c$ denotes consumption, $d$ distributions from businesses to their owners, $\ell$ labor services, and $\pi$ profits. Note that sector 2 businesses are not subject to the corporate profit tax and must distribute all their profits to their owners.

(ii) Age-dependent lump-sum transfers to households $\left\{\psi_{t}^{j}\right\}$.

(iii) Government debt $\left\{B_{t}\right\}$.

(iv) Pure public good consumption $\left\{G_{t}\right\}$.

Constraints on the stock of government debt relative to GNP are

$$
B_{t} \leq \phi_{B t} G N P_{t}
$$

where $\phi_{B t}$ are policy-constraint parameters. The motivation for this constraint is that empirically governments have limited ability to commit to honor their sovereign debt promises.

The final set of policy variables is the public goods consumptions $\left\{G_{t}\right\}$, which are given fractions of GNP:

$$
G_{t}=\phi_{G t} G N P_{t}
$$




\section{The households' problem}

Savings are in the form of an annuity which makes payments to a cohort in their retirement years conditional on them being alive. All in a cohort enter symmetrically and there are no nonconvexities. Consequently, all retirees of a given age at a point in time agree as to their optimal retirement distribution. Effectively the return on savings depends upon the survival probability as well as the interest rate.

Symbol $\ell$ denotes labor services of a household. Aggregate labor supply $L$ is

$$
L=\sum_{j} n_{j} \ell_{j} .
$$

The value function of an individual of age $j \in\{1,2, \ldots, J\}$ satisfy

$$
v_{j}(a, s)=\max _{a^{\prime}, c, \geq \geq 0}\left\{u(c, \ell)+\sigma_{t}^{j} \beta v_{j+1}\left(a^{\prime}, s^{\prime}\right)\right\}
$$

subject to

$$
\begin{aligned}
& a^{\prime} \sigma_{t}^{j}=\left(1+i_{t}\right) a+\left(1-\tau_{t}^{\ell}\right) w_{t} \ell-\left(1+\tau_{t}^{c}\right) c+\psi_{t}^{j} \\
& s^{\prime}=F(s) .
\end{aligned}
$$

In the above, $v_{J+1}=0$. Note that households aged $j>J_{R}$ are retired and their $\ell^{\prime} s$ are zero. Note also, a component of the state is $t$. The equilibrium law of motion of the aggregate state variable $F$ is taken as given by the private agents.

\section{Technology}

There is a sector that is subject to the corporate income tax and that produces intermediate good $Y_{1 t}$ and a sector that produces intermediate good $Y_{2 t}$. The aggregate production function of the composite final good $Y_{t}$ is

$$
Y_{t}=Y_{1 t}^{\theta_{1}} Y_{2 t}^{\theta_{2}},
$$


where the exponents are positive and sum to 1.

The aggregate sectorial production function are Cobb-Douglas with inputs of tangible capital $K_{i T t}$, intangible capital $K_{i I t}$, and labor $L_{i t}$ :

$$
Y_{i t}=K_{i T t}^{\theta_{i T}} K_{i I t}^{\theta_{i I}}\left(\Omega_{t} L_{i t}\right)^{1-\theta_{i T}-\theta_{i I}} \text { for } i=1,2 .
$$

Labor-augmenting technical level at date $t$ in both sectors is $\Omega_{t}$, which grows at rate $\gamma$, so

$$
\Omega_{t+1}=(1+\gamma) \Omega_{t} .
$$

Capital stocks depreciate at a constant rate, so

$$
\begin{aligned}
& K_{i T, t+1}=\left(1-\delta_{i T}\right) K_{i T t}+X_{i T t} \text { for } i=1,2 \\
& K_{i I, t+1}=\left(1-\delta_{i I}\right) K_{i I t}+X_{i I t} \quad \text { for } i=1,2
\end{aligned}
$$

where $T$ and $I$ denote tangible and intangible, respectively, and $X$ is investment. Depreciation rates are $\delta$ and are indexed by sector and capital type.

The resource balance constraint is

$$
Y_{t}=C_{t}+X_{T t}+X_{I t}+G_{t}
$$

where $X_{T t}=\sum_{i} X_{i T t}$ and $X_{I t}=\sum_{i} X_{i I t}$.

\section{Government budget constraints}

Some notation must be set up before the law of motion for government debts can be specified.

The prices of the intermediate good relative to the final good are $p_{1 t}$ and $p_{2 t}$. Sector 1 accounting

profits are

$$
\Pi_{1 t}=p_{1 t} Y_{1 t}-w_{t} L_{1 t}-X_{1 I t}-\delta_{1 T} K_{1 T t}
$$

and distributions to its owners are

$$
D_{1 t}=\left(1-\tau_{1 t}^{\pi}\right) \Pi_{1 t}-K_{1 T, t+1}+K_{1 T t} .
$$


Sector 2 distributions to its owners are

$$
D_{2 t}=\Pi_{2 t}=p_{2 t} Y_{2 t}-w_{t} L_{2 t}-\delta_{2 T} K_{2 T t}-X_{2 I t} .
$$

We can now specify the law of motion of government debt. It is

$$
B_{t+1}=B_{t}+i_{t} B_{t}+\sum_{j} n_{t}^{j} \psi_{t}^{j}+G_{t}-\tau_{t}^{c} C_{t}-\tau_{1 t}^{\pi} \Pi_{1 t}-\tau_{1 t}^{d} D_{1 t}-\tau_{2 t}^{d} D_{2 t}-\tau_{t}^{\ell} w_{t} L_{t} .
$$

Thus, next period's debt is this period's debt plus interest on this period's debt, plus transfers, plus public consumption, minus tax revenues. Taxes are levied on consumption, on business sector 1 profits, on distributions of sector 1 firms to their owners, on distributions of sector 2 firms to their owners, and on labor income.

\section{Equilibrium conditions}

Equilibrium conditions are

(i) Labor, capital, and goods markets clear at each point in time. ${ }^{6}$

(ii) The Household policy functions $\left\{a^{\prime}=f_{j}(s)\right\}_{j}$ imply the aggregate law of motion

$$
s^{\prime}=F(s) .
$$

\section{The Accounts for the Economies}

The primary sources of economic statistics used in this study are the U.S. NIPA accounts and fixed assets tables. Adjustments to the accounts are made so that they better conform to the theory used to construct the model economy that we use to draw inference.

\footnotetext{
${ }^{6}$ In the Appendix available at the Minneapolis Federal Reserve Bank website, we provide details of the algorithm used to compute equilibria.
} 


\section{NIPA accounts}

We use balanced growth numbers to restrict the model economy. Therefore, we look at average numbers over a decade. The numbers in Table 1 are the values of U.S. adjusted NIPA, where all variables are relative to adjusted GNP and averaged over the period 1999-2008. The adjustments made are as follows.

The first adjustment is that services of consumer durables are imputed and added to consumption. This consumption component is consumer durable depreciation plus the product of the average after-tax real return on non-consumer durable capital and the beginning-of-year stock of consumer durables. The after-tax real return used is 4 percent.

Consumer durable expenditures are categorized as investment. On the income side of the national accounts, we add consumer durable depreciation to NIPA depreciation and imputed consumer durable rents less depreciation to rental income of households.

The second adjustment entails dividing government consumption into two parts, a pure public good component and a local public good component. The local public good component is added to private consumption. Thus, we treat local public goods as transfer-in-kind to households. We follow the NIPA convention of using depreciation as the measure of services of government capital provided in government production. We, however, also add the 4 percent after-tax average return on non-public capital times the stock of this government capital to government production. Government output is used for government consumption and for making transfers in kind to households.

The third adjustment is that we subtract the sales tax part of Taxes on Production and Imports from capital income on the income side and from consumption on the product side. 
Thus, unlike NIPA, we are consistent in using business sector prices in constructing the national income and product accounts.

\section{Fixed assets tables}

The stock of capital is the value of capital at its reproduction cost. The Bureau of Economic Analysis (BEA) reports its estimate of this value in its Fixed Assets Tables. We add the value of intangible capital owned by private businesses as part of the aggregate capital stock as estimated by McGrattan and Prescott (2010). The stock of business intangible capital is large, averaging 1.7 over the 10-year period 1999-2008. We do not include human capital owned by individuals in the capital stock because retired people do not rent their human capital to the business sector and cannot sell it in order to finance retirement consumption. This human capital stock is large with estimates of just that part acquired on the job are 2.0 times GNP and abstracting from this stock would not be appropriate when addressing some other questions. ${ }^{7}$ We include land in the tangible capital stock, because it is in large part a produced asset associated with real estate development.

Table 2 reports the value of the stocks of capital. For stocks with positive investments, an equilibrium condition is that these replacement cost values are the present value of the rental services provided by the stock. As most types of capital are produced at a point in time, we simply use these replacement numbers as the values recognizing this leads to a modest overstatement of the market value of the capital stock.

\footnotetext{
${ }^{7}$ This is the independent estimates of Heckman, Lochner, and Taber (1998) and Parente and Prescott (2000).
} 


\section{Parameter Selection}

\section{Policy variables}

Table 3 reports the tax rates used in the analysis. There are two categories of businesses that are subject to very different taxation. The first category are Schedule C corporations that are subject to the corporate income tax. The corporate income tax rate $\tau_{1}^{\pi}$ is about 40 percent for the United States. This rate is estimated by summing federal and state corporate income taxes collected for C corporations and dividing by total corporate profits. There is an additional tax on distributions $\tau_{1}^{d}$ by these corporations, where distributions are in the form of dividends and buy-backs. This tax rate is about $20 \%$ on distribution of these corporations including both federal state income taxes over the period 1999-2008.

The second category of businesses is composed of those that distribute their accounting earnings to their owners and whose earnings are treated as ordinary income for income tax purposes and taxed at rate $\tau_{2}^{d}$. This business category includes unincorporated businesses, REITS, and Schedule S corporations. We add household businesses to this set. The primary output of household businesses is imputed rents of real estate and consumer durables that are used by the owning household. Owner-used real estate is subject to sizable property taxes in the United States. These property taxes are treated as taxes on the returns to property used in a business. In the case of household business capital, the tax rates on capital services are about 40 percent.

There are two other major differences in the household business sector and other sector 2 business sectors. First, the implicit rental income associated with implicitly renting householdowned real estate to itself is not taxed. Second, household businesses implicitly renting real estate to the household owning that business is not permitted to claim depreciation expenses. 
These two factors are of opposite sign and comparable magnitudes. For this research, given the small size of this sector, the abstraction error resulting from combining this sector with the other parts of the private business sector that are not subject to the corporate income tax is small.

The final business sector is the government production sector, whose values added is about an eighth of GNP. There are additional implicit taxes associated with government businesses and additional transfers. Thus, we think just aggregating it with the non corporate tax paying sector is reasonable as it affects little the quantitative findings reported in this paper. Our strategy is to develop and use as simple an abstraction as possible to answer the questions we are addressing. Even with this strategy, the abstraction is far from simple and to model all the unimportant details of the tax system would greatly complicate the analysis.

The labor tax $\tau^{\ell}$ is Social Security and Medicare taxes including employer as well as worker tax payments. The high consumption tax rate $\tau^{c}$ at 41.7 percent is in large part due to our categorizing income taxes as consumption taxes. The reason for this categorization is that most U.S. households can on margin defer receipt of income and payment of taxes to the time retirement consumption occurs. Virtually all non-consumed income is deferred, so to a first approximation, the U.S. income tax system is a consumption-tax system with a convex tax schedule.

We set the level of government consumption to 0.042 times GNP for all periods. Thus $\phi_{G t}=0.042$ for all $t$. This is the average share of military expenditures in the baseline economy.

We set the maximum government debt parameter $\phi_{B t}=0.75$ for all $t$. We emphasize that government debt does not include the debt in government trust funds. Some U.S. government debt is foreign held. This is another feature of reality from which we abstract. 


\section{Others parameters}

The other parameters are reported in Table 4. The utility function is logarithmic,

$$
u(c, \ell)=\log c+\alpha \log (1-\ell)
$$

Preference and technology parameters were selected so that the model's growth rates, hours of work, tangible investment shares, and capital-output ratios roughly coincide with U.S. statistics.

Table 5 reports aggregate transfers relative to GNP. The amount of transfers to workers may seem large and are much larger than those reported in NIPA. They are large because we impute large equal-size imputations to government tax revenues and to government transfers. The reason we make this large imputation is that we want the model's tax rate to be approximately equal to the income-weighted average marginal income tax rate for the U.S. tax system. Thus, we calibrate the model to estimates of average marginal tax rates and not to average tax rates. Total government revenue is much larger than collected tax revenue because important components of income are not taxed and because the income tax schedule is convex. We impute transfers equal to the difference between what tax revenues would be if all income were taxed at the marginal rates and what actual tax revenues are.

One item that is not subject to income taxes is fringe benefits, which are about 25 percent of total compensation. We treat the product of average marginal income tax rate and fringe benefits as an implicit transfer and tax revenue. We treat government non-military purchases of goods and services as transfers in-kind. An important part of these expenditures are for public education, which are primarily transfers to workers and not to retirees. The final large imputed transfer is the difference between income tax receipts if all personal income were taxed at the average marginal rate and the actual income tax revenues. 


\section{Baseline model accounts}

The national accounts for the baseline economy are reported in Table 6 for the policy variables and parameters shown in Tables 3-5. Note that income and product are equal to total output less intangible investment, which is expensed. Government spending is pre-set and all other quantities are found by computing an equilibrium for the baseline parameters.

\section{Market value of business equity}

For our closed economy, private savings is equal to business equity plus government debt. In this subsection we compare the baseline model economy's private net worth with the private net worth values reported in the Federal Reserve System's Flow of Funds accounts.

With taxes, the market value of business equity is less than the value of business capital less net business debt. The value of corporate business equity is approximately equal to the predictions of theory as shown in McGrattan and Prescott (2005) for the United States and the United Kingdom. ${ }^{8}$ The equilibrium relations used to predict the $V_{i}$, the market values of the business sectors, are

$$
\begin{aligned}
& V_{1}=\left(1-\tau_{1}^{d}\right) K_{1 T}^{\prime}+\left(1-\tau_{1}^{d}\right)\left(1-\tau_{1}^{\pi}\right) K_{1 I}^{\prime} \\
& V_{2}=K_{2 T}^{\prime}+\left(1-\tau_{2}^{d}\right) K_{2 I}^{\prime} .
\end{aligned}
$$

The reason for the $\left(1-\tau_{1}^{d}\right)$ factor in the first equation is if retained earnings are use to finance tangible investment, the cost of a unit of capital in terms of the composite output good is $\left(1-\tau_{1}^{d}\right)$. In fact, virtually all investment in sector 1 is financed by retained earnings. The reason for the $\left(1-\tau_{1}^{\pi}\right)$ factor is that intangible capital investments are expensed and this reduces taxable accounting profits. For sector 2, all profits except those used to finance intangible capital investment are distributed to the households who own the business.

\footnotetext{
${ }^{8}$ These relations hold provided investments in the capital stocks are strictly positive.
} 
The total value of the business sector is

$$
V=V_{1}+V_{2},
$$

which is the value of both net private business debt and equity held directly and indirectly. Theory predicts private net worth equals business equity $V$ plus government debt $B$. We are using the fact that the purchaser's price for tangible capital is approximately 1 as the capital consumption allowance adjustments over the period 1999-2008 were small as were investment tax credits and taxes on capital equipment.

The Flow of Funds reported net worth of the private sector that average 4.1 GNPs in the 1999-2008 period. This turns out to be smaller than the 5.5 GNPs number predicted by our baseline model given our estimates of marginal tax rates.

To obtain the model prediction we begin with the capital stock of 5.7 GNPs. We make the tax adjustments for taxes on distributions of sector 1 businesses and for the consequence of intangible-capital investment being expensed. This leads to a value of model business equity equal to 4.7 GNPs. To this we add government debt to obtain a predicted private net worth of 5.5 GNPs.

There are several factors that need to be considered when comparing predicted and reported private net worth. First, the stock of 5.7 GNPs includes about 0.6 GNPs of public fixed assets that are legally owned by the government and not included in U.S. household net worth reported by the Federal Reserve. Second, about 0.2 GNPs of U.S. government debt is foreign owned and not part of U.S. household net worth. We could not include it because our model is a closed economy. Third, the stock market in the period considered was below predicted by a sizable amount. Fourth, our baseline model has no aggregate uncertainty and as a result there is no aggregate risk-premium. Fifth, some tangible capital has a q-value less than one because of 
government subsidies and because there is an excessive supply of some capital goods that result in no new capital of that type being produced. Sixth, the Flow-of-Funds estimate of the value of sector 2 businesses are not that well measured and almost surely low. Owners of corporations that are not publically traded often have an incentive to undervalue the value of their businesses.

Given these considerations, the discrepancy between predicted private net worth and private net worth as reported in the Flow of Funds account is not large enough to cast doubt on the appropriateness of the model used in this analysis.

\section{Evaluation of Alternative Retirement Finance Systems with Current and New Demographics}

We use the calibrated model with the annual growth rate of new entrants into the population being either 0 or 1 percent and evaluate two alternative policy regimes. The first policy regime is to continue current tax policies which entail increasing the labor income tax rates over time to finance retirement transfers necessitated by the falling number of workers per retiree. The second policy regime eliminates all capital income taxes, the labor income tax, and the part of the transfers to retirees that are neither welfare nor local public goods.

In this section, we report the welfare consequences for the two alternative policies given that the initial state is the one for the balanced growth-path state for the baseline economy specified in Section 4. Time $t=0$ is when the demographic transition occurs. Those entering the workforce in a given year are a cohort. Thus cohort t entered the workforce at time t. At the time of transition the cohorts as indexed by year of workforce entry are $t \in\{-41,-40, \ldots, 1,0\}$ and the retired cohorts at $t \in\{-101,-100, \ldots,-42\}$. We determine the welfare consequences for each cohort with members alive at the time of the unexpected demographic and policy regime change 
and the welfare of all cohorts entering the workforce years subsequent to the demographic change. But, first we examine the balanced growth policies of the two policy regimes.

\section{Two retirement financing policies}

Tables 7 and 8 report the tax rates and transfers for the two alternative policies. The first policy is sticking with the current system with increased taxes on labor income used to finance transfers to retirees. This necessitates the labor tax rate be increased from 15 percent to 25 percent over time. Total transfers to the old are larger than this number because there are transfers in-kind made by state and local governments. What correspond to labor taxes are FICA and Medicare taxes. Income taxes are treated as consumption taxes as nearly all household income is either consumed or saved in deferred compensation retirement accounts. These savings are taxed when used to finance retirement consumption.

\section{Balanced growth comparisons}

We first compare the balanced growth equilibrium, varying demographics and policies. The balanced growth results are reported in Tables 9 to 12. In each table, we label the baseline economy as that with current demographics and current policies. The first alternative economywith current demographics and new policy—is the same as the baseline except that taxes and transfers are changed. (See Tables 7 and 8.) The two remaining economies considered are based on new demographics, with 0 percent growth in population and two workers per retiree rather than three.

Table 9 reports summary statistics for the four economies. All variables have been normalized to 1 in the economy with new demographics and current policy to make comparisons easier. In the economies with the new policy, GNP is significantly higher, with the added output made possible by increased labor and capital inputs. Under current demographics, the total labor 
input is slightly higher because a larger fraction of the population is working. Welfare and consumption are also significantly increased with the new policy, whether or not the demographics change, when compared to the economy with new demographics and current policy. For example, welfare is higher by 23.2 percent and consumption is higher by 46.8 percent when taxes on incomes and distributions are eliminated, holding fixed the demographics.

Tables 10-12 show how the model's national accounts, fixed assets tables, and flow of funds change as we vary policies and demographics. The results in these tables are all shown relative to GNP. Table 10 shows that eliminating income taxes implies a dramatic shift in consumption and investment shares of GNP and the allocation of profits across corporate and non-corporate entities that are taxed differently. Table 11 shows that the capital-output ratios, especially the tangible capital-output ratios, increase dramatically when income taxes are eliminated. The results are even more dramatic if we consider the impact on market values, which are shown in Table 12. The market values are a function of both tax rates and capital stocks. Eliminating taxes increases the price of capital and the quantity. This is especially true for the intangible market values which roughly double when income taxes are eliminated.

\section{Welfare comparisons by cohorts}

A question that arises is what are the welfare consequences in the transition to balanced growth. Do some birth-year cohorts lose? Answering this question requires computing the equilibrium transition path. Given the state variable of the economy has a high dimension, computing the equilibrium is computationally intensive and only recently has there been the computation power to carry out these computations in a reasonable amount of time. We have calculated the transition paths for the two policies. We emphasize that there are transfers over the remainder of their lifetime to those alive at the time of the demographic change for the alternative policy 
regime. The paths of age-dependent transfers and tax rates are reported in the Appendix for the new policy. ${ }^{9}$

Figure 1 plots the welfare gains in remaining lifetime consumption-equivalents of cohorts by age at the time $t=0$, when growth in the number of new workers falls from 1 percent per year to 0 percent per year. An important point is that current retirees and those currently near retirement do not lose. Promised retirement transfers are made to these groups. All age cohorts from the currently old benefit. Gains for retirees are on the order of 5 percent. Gains for current workers that can take advantage of lower taxes are closer to 6 percent. Gains for future cohorts are in the range of 6 to 23 percent. This is a Paretto improving outcome.

\section{Summary and Concluding Remarks}

We find that the fall in the number of workers per retiree can be handled without major change in the retirement financing scheme. However, there are tax policy changes that dramatically increase welfare. These changes entail eliminating capital income taxes and relying more on saving for retirement and less on lump-sum transfers to retirees.

We see this analysis as significantly advancing our understanding of alternative policies to finance retirement consumption. The broadening of the (non-human) capital stock is important as is requiring the model to be consistent with both capital accounts and net worth accounts. Also important is the recognition that including implicit transfers, increases the size of the government sector from about 35 percent to 44 percent of U.S. GNP.

Through discussions and insights we hope and expect that better abstractions for predicting the consequences of alternative tax and transfer policies will develop. We have costless and perfect annuitization and no bequest motive. Introducing these would increase the

\footnotetext{
${ }^{9}$ The appendix is available at the Minneapolis Federal Reserve Bank website.
} 
stock of savings. On the other hand we do not model the rival human capital investments made over working lives and this may have a consequence for the stock of savings. ${ }^{10}$

Another point is that mandatory savings and insurance mitigates the problem of some people not saving enough for retirement and outliving their savings. Mandatory savings and insurance, which are not binding for most people, do not distort the labor-leisure and intertemporal consumption choices.

${ }^{10}$ Johanna Wallenius (2011) has analyzed the consequence of rival human capital production on the job for the intertemporal elasticity of substitution of labor, but did not focus assess the consequence for the aggregate stock of savings. 


\section{References}

Abel, Andrew B., N. Gregory Mankiw, Lawrence H. Summers, and Richard J. Zeckhauser. 1989. Assessing Dynamic Efficiency: Theory and Evidence. Review of Economic Studies 56: 1-19.

Auerbach Alan J. and Laurence J. Kotlikoff. 1987. Dynamic Fiscal Policy (Cambridge, Cambridge University Press).

Bell, Felicitie C., and Michael L. Miller. 2005. Life Tables for the United States Social Security Area 1900-2100, Actuarial Study No. 120. Social Security Administration Publication No. 11-11536.

Board of Governors. 1945-2005. Flow of Funds Accounts of the United States. Statistical Release Z.1. (Washington, D.C.: Board of Governors of the Federal Reserve System).

Birkeland, Kathryn and Edward C. Prescott. 2007. On the Needed Quantity of Government Debt. Federal Reserve Bank of Minneapolis Quarterly Review 31(1): 2-15.

Conesa, Juan Carlos, Sagiri Kitao, and Dirk Krueger. 2009. Taxing Capital? Not a Bad Idea after All! American Economic Review 99(1): 25-48.

Conesa, Juan Carlos and Dirk Krueger. 1999. Social Security Reform with Heterogeneous Agents. Review of Economic Dynamics 2(4): 757-795.

De Nardi, Mariacristina, Selahattin Imrohoroglu, and Thomas J. Sargent. 1999. Projected U.S. Demographics and Social Security. Review of Economic Dynamics 2(3): 575-615.

Heckman, James J., Lance Lochner, and Christopher Taber. 1998. Explaining Rising Wage Inequality: Explorations with a Dynamic General Equilibrium Model of Labor Earnings with Heterogeneous Agents. Review of Economic Dynamics 1(1): 1-58.

Krueger, Dirk and Felix Kubler. 2002. Intergenerational Risk Sharing via Social Security when 
Financial Markets are Incomplete. American Economic Review 92(2): 407-410.

McGrattan, Ellen R. and Edward C. Prescott. 2005. Taxes, Regulations, and the Value of U.S. and U.K. Corporations. Review of Economic Studies 72(3): 767-796.

McGrattan, Ellen R. and Edward C. Prescott. 2010. Technology Capital and the U.S. Current Account. American Economic Review 100(4): 1493-1522.

Parente, Stephen L. and Edward C. Prescott. 2000. Barriers to Riches (Cambridge, Mass.: MIT Press).

Rossi-Hansberg, Esteban and Mark L. J. Wright. 2007. Urban Structure and Growth. Review of Economic Studies 74(2): 597-624

Thompson, Earl A.. 1967. Debt Instruments in Both Macroeconomic Theory and Capital Theory. American Economic Review 57(5): 1196-1210.

U.S. Department of Commerce, Bureau of Economic Analysis. 1929-2005. National Income and Product Accounts of the United States Survey of Current Business (Washington, DC: U.S. Government Printing Office).

Wallenius, Johanna. 2011. Human Capital Accumulation and the Intertemporal Elasticity of Substitution of Labor: How Large is the Bias?. Review of Economic Dynamics 14(4): 577-591. 
TABle 1. Revised National InCOME AND PRoduct AcCounts,

AVERAGES Relative TO GNP, 1999-2008

TOTAL ADJUSTED INCOME

1.000

Labor Income

.594

Compensation of employees (NIPA 1.10) $\quad .539$

70\% of proprietors' income (NIPA 1.10)

Capital Income $\quad 238$

Corporate profits with IVA and CCadj (NIPA 1.10)

$30 \%$ of proprietors' income (NIPA 1.10) 023

Government enterprises (NIPA 1.10) $\quad .000$

Rental income of persons with CCadj (NIPA 1.10) 016

Net interest and miscellaneous payments (NIPA 1.10) 057

Statistical discrepancy (NIPA 1.10) -.005

Taxes on production and imports $^{b}$ (NIPA 1.10) $\quad 029$

Less: Sales tax (NIPA 3.5)

Imputed capital services ${ }^{c}$ (FA 1.1) $\quad .036$

Net income, rest of world (NIPA 1.13)

Tangible Depreciation $\quad .168$

Consumption of fixed capital (NIPA 1.10) $\quad .116$

Consumer durable depreciation (FOF F.10)

TOTAL AdJUSTED PRODUCT 1.000

$\begin{array}{ll}\text { Consumption } & .738\end{array}$

Personal consumption expenditures (NIPA 1.1.5) $\quad .659$

Less: Consumer durables (NIPA 1.1.5)

Less: Sales tax, nondurables and services $\quad .036$

Consumer durable depreciation (FOF F10)

Government consumption, nondefense (NIPA 3.9.5) $\quad .110$

Imputed capital services $^{c} \quad 036$

See footnotes at the end of the table. 
TABle 1. Revised National InCome And Product AcCounts,

AVERAGES Relative TO GNP, 1999-2008

Government spending

Government expenditures, national defense (NIPA 1.1.5) $\quad .042$

Tangible investment $\quad .222$

Gross private domestic investment (NIPA 1.1.5) $\quad .156$

Consumer durables (NIPA 1.1.5)

Less: Sales tax, durables $\quad .005$

Government investment, nondefense (NIPA 3.9.5) $\quad .025$

Net exports of goods and services (NIPA 1.1.5) $\quad-.043$

Net income, rest of world (NIPA 1.13) $\quad 006$

Note: IVA, inventory valuation adjustment; CCadj, capital consumption adjustment; NIPA, national income and product accounts; FA, fixed assets; FOF, flow of funds.

${ }^{a}$ Expressions in parentheses are the data sources and table numbers.

${ }^{b}$ This category includes business transfers and excludes subsidies.

${ }^{c}$ Imputed capital services are equal to 4 percent times the current-cost net stock of government fixed assets and consumer durables goods. 
TABLE 2. REVISED FIXED ASSET TABLES, AVERAGES Relative TO GNP, 1999-2008 ${ }^{a}$

TANGIBLE CAPITAL, END OF PERIOD

4.053

Private assets, private (FA 1.1)

2.175

Fixed assets, public (FA 1.1) .580

Consumer durables (FA 1.1) .306

Inventories (NIPA 5.7.5)

.137

Land (FOF B.100-B.103)

.856

INTANGIBLE CAPITAL, END OF PERIOD

1.718

Plant specific, McGrattan-Prescott (2010)

1.198

Technology capital, McGrattan-Prescott (2010)

TOTAL

5.771

Note: FA, fixed assets; FOF, flow of funds.

${ }^{a}$ Expressions in parentheses are the data sources and table numbers.

TABle 3. Policy VARiables Used in CALIBration

\begin{tabular}{cl}
\hline \hline$\tau_{1}^{\pi}$ & 0.400 \\
$\tau_{1}^{d}$ & 0.200 \\
$\tau_{2}^{d}$ & 0.400 \\
$\tau^{\ell}$ & 0.150 \\
$\tau^{c}$ & 0.417 \\
$\phi_{G}$ & 0.042 \\
$\phi_{B}$ & 0.750 \\
\hline
\end{tabular}


TABle 4. Parameters of the EConomy Calibrated to U.S. DATA

\section{Demographic parameters}

Growth rate of population

Work life

Number of workers per retirees

Preference parameters

$\alpha$

$\beta$

\section{Technology parameters}

$\begin{array}{lc}\theta_{1} \text { and } \theta_{2} & 0.500 \\ \delta_{1 T} & 0.060 \\ \delta_{2 T} & 0.060 \\ \delta_{1 I} & 0.030 \\ \delta_{2 I} & 0.030 \\ \gamma & 2.0 \% \\ \theta_{1 T} & 0.220 \\ \theta_{1 I} & 0.180 \\ \theta_{2 T} & 0.500 \\ \theta_{2 I} & 0.080\end{array}$

$1.0 \%$

42 years

3

1.300

0.987 
TABle 5. Aggregate Transfers Relative to GNP Used in CALIBRATION

\begin{tabular}{ll}
\hline \hline To retirees & 0.148 \\
$\quad$ Retirement & 0.100 \\
Local public goods & 0.048 \\
To workers & 0.292 \\
Total & 0.440 \\
\hline
\end{tabular}

Table 6. Baseline Model National Income and Product Accounts, AVERAGES RELATIVE TO GNP, 1999-2008

\begin{tabular}{ll}
\hline INCOME $\left(Y-X_{I}\right)$ & .577 \\
\hline Labor Income $(w L)$ & .423 \\
Capital Income $\left(Y-w L-\sum_{i} \delta_{i T} K_{i T}-X_{I}\right)$ & .146 \\
Tangible Depreciation $\left(\sum_{i} \delta_{i T} K_{i T}\right)$ & .059 \\
Sector 1 Corporate $\left(\delta_{1 T} K_{1 T}\right)$ & .088 \\
Sector 2 Non-corporate $\left(\delta_{2 T} K_{2 T}\right)$ & \\
& \\
PRODUCT $\left(Y-X_{I}\right)$ & .694 \\
Consumption $(C)$ & .264 \\
Tangible investment $\left(X_{T}\right)$ & .088 \\
Sector 1 Corporate $\left(X_{1 T}\right)$ & .176 \\
Sector 2 Non-corporate $\left(X_{2 T}\right)$ & .042 \\
Government $(G)$ & .110 \\
Addenda: Intangible investment $\left(X_{I}\right)$ & \\
\hline \hline
\end{tabular}


Table 7. Balanced Growth Tax Rates for Alternative Policies

\begin{tabular}{cccccc}
\hline \hline & \multicolumn{2}{c}{ Current Demographics } & & \multicolumn{2}{c}{ New Demographics } \\
\cline { 2 - 3 } \cline { 5 - 5 } \cline { 5 - 5 } & Current Policy & New Policy & & Current Policy & New Policy \\
\hline$\tau_{1}^{\pi}$ & .400 & .000 & & .400 & .000 \\
$\tau_{1}^{d}$ & .200 & .000 & & .200 & .000 \\
$\tau_{2}^{d}$ & .400 & .000 & & .400 & .000 \\
$\tau^{\ell}$ & .150 & .000 & & .250 & .000 \\
$\tau^{c}$ & .417 & .320 & & .417 & .320 \\
\hline \hline
\end{tabular}

TABle 8. BALANCED GROWTH AgGRegate TRANSFERS:

RELATIVE TO GNP

\begin{tabular}{cccccc}
\hline & \multicolumn{2}{c}{ Current Demographics } & & \multicolumn{2}{c}{ New Demographics } \\
\cline { 2 - 3 } \cline { 5 - 6 } & Current Policy & New Policy & & Current Policy & New Policy \\
\hline Total transfers & .440 & .146 & & .512 & .154 \\
To retirees & .148 & .036 & & .233 & .051 \\
To workers & .292 & .109 & & .289 & .103 \\
\hline \hline
\end{tabular}


TABLE 9. BALANCED GROWTH SUMMARY STATISTICS

Relative to New Demographics and CURRent Policy

\begin{tabular}{lccccc}
\hline \hline & \multicolumn{2}{c}{ Current Demographics } & & \multicolumn{2}{c}{ New Demographics } \\
\cline { 2 - 3 } \cline { 5 - 6 } & Current Policy & New Policy & & Current Policy & New Policy \\
\hline GNP & 1.150 & 1.730 & & 1.000 & 1.638 \\
Consumption & 1.085 & 1.450 & & 1.000 & 1.468 \\
Tangible investment & 1.361 & 2.653 & & 1.000 & 2.195 \\
& & & & & \\
Capital stock & 1.170 & 2.119 & & 1.000 & 2.044 \\
Hours per worker & 1.030 & 1.293 & & 1.000 & 1.329 \\
& & & & & 1.000 \\
Welfare & 1.080 & 1.228 & & & \\
\hline \hline
\end{tabular}


TABle 10. NATIONAL INCOME AND PRODUCT ACCOUNTS RELATIVE TO GNP, BALANCED GROWTH FOR ALTERNATIVE POLICIES

\begin{tabular}{lccccc}
\hline \hline & \multicolumn{2}{c}{ Current Demographics } & & \multicolumn{2}{c}{ New Demographics } \\
\cline { 2 - 3 } \cline { 5 - 6 } & Current Policy & New Policy & & Current Policy & New Policy \\
\hline $\mathrm{C}$ & .694 & .616 & & .735 & .659 \\
$X_{T}$ & .264 & .342 & & .223 & .299 \\
$\mathrm{G}$ & .042 & .042 & & .042 & .042 \\
$\sum_{i} \delta_{i T} K_{i T}$ & .146 & .189 & & .145 & .194 \\
$w L$ & .577 & .574 & & .567 & .568 \\
$\Pi_{1}$ & .076 & .064 & & .084 & .068 \\
$\Pi_{2}$ & .201 & .173 & & .204 & .170 \\
$X_{I}$ & & & & & .112 \\
\hline \hline
\end{tabular}


Table 11. Fixed Assets Relative to GNP, BALANCED GROWTH FOR ALTERNATIVE POLICIES

\begin{tabular}{cccccc}
\hline \hline & \multicolumn{2}{c}{ Current Demographics } & & \multicolumn{2}{c}{ New Demographics } \\
\cline { 2 - 3 } \cline { 5 - 6 } & Current Policy & New Policy & & Current Policy & New Policy \\
\hline$K_{T}^{\prime}$ & 4.016 & 5.237 & & 3.950 & 5.344 \\
$K_{T 1}^{\prime}$ & 1.010 & 1.244 & & 0.992 & 1.256 \\
$K_{T 2}^{\prime}$ & 3.006 & 3.993 & & 2.959 & 4.088 \\
$K_{I}^{\prime}$ & 1.712 & 1.656 & & 1.679 & 1.682 \\
$K_{I 1}^{\prime}$ & 1.047 & 1.018 & & 1.026 & 1.028 \\
$K_{I 2}^{\prime}$ & 0.664 & 0.639 & & 0.663 & 0.654 \\
$K^{\prime}$ & 5.728 & 6.893 & & 5.629 & 7.026 \\
\hline \hline
\end{tabular}


Table 12. Market Values of Private Sector Net Assets Relative to GNP, BALANCED GROWTH FOR Alternative POLICIES

\begin{tabular}{cccccc}
\hline \hline & \multicolumn{2}{c}{ Current Demographics } & & \multicolumn{2}{c}{ New Demographics } \\
\cline { 2 - 3 } \cline { 5 - 6 } & Current Policy & New Policy & & Current Policy & New Policy \\
\hline$V_{T}^{\prime}$ & 3.814 & 5.237 & & 3.752 & 5.344 \\
$V_{T 1}^{\prime}$ & 0.808 & 1.244 & & 0.793 & 1.256 \\
$V_{T 2}^{\prime}$ & 3.006 & 3.993 & & 2.959 & 4.088 \\
$V_{I}^{\prime}$ & 0.901 & 1.656 & & 0.884 & 1.682 \\
$V_{I 1}^{\prime}$ & 0.503 & 1.018 & & 0.493 & 1.028 \\
$V_{I 2}^{\prime}$ & 0.399 & 0.639 & & 0.392 & 0.654 \\
$V^{\prime}$ & & & & & \\
\hline \hline
\end{tabular}




\section{Figure 1}

Percentage Welfare Gain of New Policy by Cohort Age at Time of Regime Change Units: Remaining Lifetime Consumption Equivalents

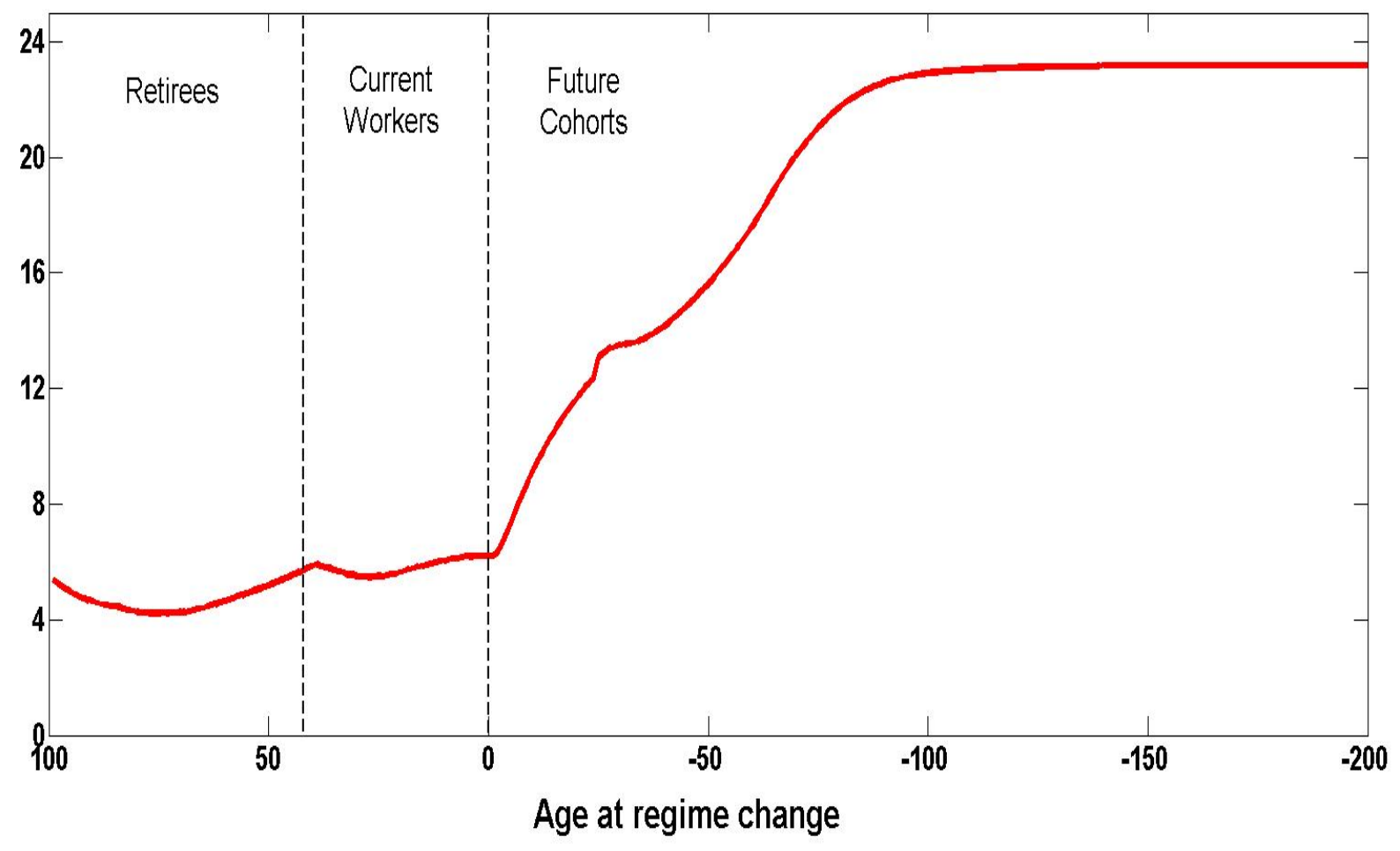

